\title{
DERTIG OF TIEN JAAR?
}

\section{door Prof. Mr J. Valkhoff}

In de Tweede titel van het Eerste boek van het Wetboek van Koophandel, "Van Boekhouding", treft men naast de wettelijke verplichting voor ieder, die een bedrijf uitoefent, tot het houden van ",aantekening" van zijn vermogenstoestand en van alles, wat zijn bedrijf betreft, de bewijskracht der boekhouding in het algemeen, de openlegging (in een proces) en de overlegging of afgifte van boeken (buiten een proces), een wettelijke plicht voor degene, die een bedrijf uitoefent, tot bewaring van de boeken, de bescheiden, de balansen, de ontvangen brieven en telegrammen en de afschriften van de uitgaande brieven en telegrammen. aan. Oorspronkelijk - in het Wetboek van Koophandel van 1838 - was de termijn van de bewaarplicht ten aanzien van boeken, waaronder toen nog een copie-boek en een balans-boek, voor de ,kooplieden" dertig jaar. Door de wetswijziging van 5 Mei 1922, S. 246, werd de termijn van verplichte bewaring voor de brieven en telegrammen (bij amendement van de Commissie van Rapporteurs) teruggebracht tot tien jaar. De Regering had toen wederom zowel voor de boeken en bescheiden, als ook voor de correspondentie een gelijke bewaringstermijn van dertig jaar voorgesteld. maar uit de kringen van het bedrijfsleven zelf werd tegen deze lange termijn voor de brieven en telegrammen op practische gronden bezwaar gemaakt. Tijdens de bezetting van ons land door de Duitsers is de termijn van de bewaarplicht, die derhalve sinds 1922 voor de boeken en bijbehorende bescheiden aanzienlijk langer was dan voor de brieven en telegrammen, voor beide gelijk gemaakt. Bij Besluit van de SecretarisGeneraal van Justitie van 23 Februari 1943 werd ook de termijn van verplichte bewaring der boeken, bescheiden en balansen teruggebracht tot tien jaar. $\mathrm{Bij}$ de bevrijding van ons land is deze regeling voorlopig gehandhaafd (artikel 16 Besluit Bezettingsmaatregelen, E 93).

De bezettingsregeling moest echter op den duur als zodanig verdwijnen en door een eigen Nederlandse wettelijke regeling in het Wetboek van Koophandel vervangen worden. De Regering stond nu voor de vraag: dient ten aanzien van de verplichte boekhouding met de daartoe behorende bescheiden alsmede de balansen de vóóroorlogse lange termijn van dertig jaar terug te keren of moet de thans nog voorlopig geldende korte termijn van tien jaar blijven? Vóór de dertigjarige termijn pleit de eenheid van rechtssysteem, gelet $\mathrm{nl}$. op de algemene termijn van de bevrijdende of extinctieve verjaring in het Vierde Boek van het Burgerlijk Wetboek. Deze is immers dertig jaar volgens artikel 2004 B. W., luidende: ,Alle regtsvorderingen, zoo wel zakelijke als persoonlijke, verjaren door dertig jaren, zonder dat hij, die zich op de verjaring beroept verpligt $z$ ij eenigen titel aan te toonen, of dat men hem eenige exceptie, uit zijne kwade trouw ontleend, kunne tegenwerpen".

In de Nederlandse leerboeken over het Handelsrecht, als die van Molengraaff, Polak, Völlmar, vond men altijd op dit systematisch verband tussen de wettelijke bepaling over de bewaarplicht voorin het Wetboek van Koophandel en de verjaringsregeling achter in het Burgerlijk Wetboek gewezen. Ook sommige Franse schrijvers als Lyon-Caen en Renault legden de nadruk op dit verband en verklaarden zich op die grond tegen de in hun land geldende bewaringstermijn van slechts tien jaar (art. 11, slot van de Franse Code de Commerce: "Les commercants 
seront tenus de conserver ces livres pendant dix ans"). Bij de parlementaire behandeling van de bovenvermelde wetswijziging van ons Wetboek van Koophandel in 1912 op het punt van de boekhouding en de bewarplicht legde ook de toenmalige Minister van Justitie, Heemskerk, de nadruk op de aansluiting met de algemene termijn voor verjaring van schuldvorderingen van dertig jaar. Onlangs nog stempelde de Leeuwardense advocaat en procureur Mr J. Rutgers in zijn niet alleen voor juristen, maar ook voor economen, accountants, ondernemers enz. belangwekkend boek over "Openlegging en overlegging van boekhouding" (met de ondertitel: "Eenige aanteekeningen bij den Tweeden Titel van het Wetboek van Koophandel en daarmede in verband staande bepalingen van privaaten publiekrechtelijken aard") de verkorte termijn van tien jaren met het oog op de ongewijzigde civielrechtelijke verjaringstermijn van dertig jaren „,als ongewenscht" (pagina 117). Theoretisch is er zo voor een bewaarplicht van dertig jaar iets te zeggen. Zo oordeelde ook de Regering, want op 26 November 1948 werd er door haar een Ontwerp van wet tot vervallenverklaring van de bezettingsregeling betreffende de termijn van bewaring van boeken, bescheiden en balansen van bedrijven ingediend, dat slechts één artikel behelsde, waardoor de termijn in artikel 6 Wetboek van Koophandel wederom, als vóór 1943, dertig jaar zou worden.

Er bestaan echter sterke argumenten voor een kortere bewaringstermijn. Allereerst is de vraag gerechtvaardigd of de algemene dertigjarige termijn van de bevrijdende verjaring van schuldvorderingen voor de tegenwoordige tijd niet te lang is. Het levenstempo is, vergeleken met de tijd, waarin onze nationale codificatie van het privaatrecht tot stand kwam (1838), ontzaglijk versneld. Wij glimlachen nu, wanneer wij in de nog uit genoemd jaar stammende wettelijke regeling van de zeeverzekering in het Tweede Boek van het Wetboek van Koophandel bij het abandonnement artikel 667 lezen. Daar zien we immers nog termijnen in verband met de tijdingloosheid enz. genoemd, die met het oog op de afstanden tussen Nederland en de diverse havens en kusten in Europa of in andere werelddelen variëren van 6 tot 12 maanden en zelfs 18 maanden. Welke ingrijpende veranderingen hebben moderne communicatiemiddelen als de stoomvaart, de motorvaart, de luchtvaart, de telegraaf, de telefoon, de radio e.d. in dit opzicht gebracht! „De afstanden hadden een geheel andere betekenis dan tegenwoordig", schreef ik, dit illustrerend met voorbeelden, in mijn ,Een eeuw rechtsontwikkeling”, blz. 12 (tweede druk 1949). Wanneer Mr Völlmar in zijn ,Unificatie van het Handelsrecht in Nederland en België" (1948) op blz. 69 schrijft: „,Moeten de termijnen bij tijdingloosheid niet worden herzien?", klinkt de vraag bijna ironisch en is slechts een bevestigd antwoord verwacht. In de betreffende Amsterdamse en Rotterdamse beurscondities worden deze verouderde termijnen van artikel $667 \mathrm{~W}$. v. K., dat aanvullend recht behelst, dan ook bij vermissing practisch aanzienlijk verkort. „Deze van de wet afwijkende regeling vond haar oorzaak in het snellere verkeer, waardoor de twijfel in geval van vermissing eerder verdwijnt", schrijft Dorhout Mees in zijn Handboek over "Schadeverzekeringsrecht" (blz. 567). Toen het eigenlijke zeerecht in het Tweede boek van het Wetboek van Koophandel eindelijk vernieuwd werd - een modernisering, waaraan voor altijd de naam van Molengraaff verbonden blijft — zijn vele verjaringstermijnen daarin dan ook belangrijk korter gemaakt. Hetzelfde gebeurde in het wisselrecht, toen dit in het jaar 1932 in ons land een vernieuwing onderging. 
$B \mathrm{ij}$ het vermoeden (in artikel 270 van het Wetboek van Koophandel; zie ook artikel 597), dat men van de aanwezigheid der schade heeft kunnen kennis dragen, zal de rechter nu wel heel wat eerder dan honderd jaar geleden met inachtneming der omstandigheden oordelen, dat „er sedert het aanwezen der schade zoo veel tijds is verloopen, dat de verzekerde daarvan had kunnen kennis dragen". Er bestaat derhalve een onmiskenbare en ook begrijpelijke tendentie in de rechtsontwikkeling de verjaringstermijnen te verkorten; een punt, dat zeker bij het totstandbrengen van een geheel nieuw Burgelijke Wetboek, waaraan thans, naar men weet, door de Leidse hoogleraar E. M. Meyers in opdracht van de Regering gewerkt wordt, de aandacht zal hebben.

Intussen, de dertigjarige termijn van extinctieve verjaring zal nog wel enige tijd in ons privaatrecht gelden. Er bestaan echter klemmende redenen om de bewaringstermijn nu reeds van de dertigjarige verjaringstermijn los te maken, zoals de bezettingsregeling deed. De ervaringen met de tienjarige termijn bij de bewaring van de correspondentie sinds 1922 zijn gunstig. Van practische bezwaren tegen de huidige tienjarige termijn bij de boeken, bescheiden en balansen wordt, naar mijn weten, niet gehoord; evenmin als men practische bezwaren verneemt uit Frankrijk en België, waar de bewaringstermijn reeds zo lang tien jaar is. De dertigjarige bewaringsplicht brengt voor het bedrijfsleven last en rompslomp met zich mee, ervan afgezien dat hij niet altijd nageleefd wordt. Het zal zelden voorkomen, dat er zich na een tijd van tien jaar nog onverwacht serieus door derden aangelegde procedures in verband met de boeken uit vroeger tijd voordoen. De bedrijfsleiding kan, wanneer zij de mogelijkheid van latere geschillen en rechtsvorderingen ducht, ook zonder dat zij daartoe wettelijk verplicht is, de belangrijkste delen van de boekhouding en bepaalde bescheiden als facturen, quitanties, koopbriefjes e.d. met het oog op bijzondere omstandigheden vrijwillig langer dan de voorgeschreven tien jaar bewaren, om later tot bewijs te kunnen dienen.

Tot mijn voldoening vond men in het Voorlopig Verslag van de Vaste Commissie voor Privaat- en Strafrecht in de Tweede Kamer der StatenGeneraal over het wetsontwerp tot vervallenverklaring van de bezettingsregeling betreffende de termijn van bewaring der boeken, bescheiden en balansen bovengenoemde argumenten tegen een bewaringstermijn van dertig jaar en vóór een korte bewaringstermijn van tien jaar, zij het voorzichtig gesteld en veelal vragenderwijs, aangeduid. $Z_{i j}$ zijn inderdaad klemmend en het stemt tot verheugenis, dat de Regering, na nieuw beraad, zich er door heeft laten overtuigen. Bij de Memorie van Antwoord - die lang op zich liet wachten, maar erkend dient, dat de Regering thans andere en belangrijker zorgen heeft dan deze, overigens voor het zakenleven geenszins onbelangrijke aangelegenheid - van 24 September j.l. koos ook de Regering de tienjarige termijn. Het Gewijzigd Ontwerp behelst nu twee artikelen; een, waarbij de bezettingsregeling van 1943 vervallen verklaard wordt, en een tweede, volgens hetwelk in artikel 6, derde lid van het Wetboek van Koophandel de woorden ,,dertig jaar" vervallen, waardoor dan voor de verplichte boeken en bescheiden, de balansen en de correspondentie alle een gelijke wettelijke bewaringstermijn van tien jaren zal gelden.

Wordt dit Gewijzigd Ontwerp wet, dan zal dus materieel hetzelfde gelden als de bezettingsregeling behelsde, doch nu formeel als Nederlandse wet, tot stand gebracht door Koning en Staten-Generaal. Uit deze gang van zaken concludere men nu niet, dat de wijze van regeling 
in de bezettingstijd, waardoor met één slag en zonder vertraging een nieuwe regeling van de bewaringstermijn kwam, die stellig de voorkeur verdient boven de verouderde in het Wetboek van Koophandel, toch nog niet zo kwaad was. Ten eerste hadden de tot-stand-brenging en de invoering van de bezettingsregeling bij Besluit geen eigenlijke juridische grond, doch geschiedden zij primair om louter utilitaire redenen, nl. als een middel om de nijpende papiernood in ons land door opruiming van de oude boeken en bescheiden, die trouwens dikwijls reeds in deplorabele toestand verkeerden of ernstig aan leesbaarheid ingeboet hadden, enigszins te helpen verlichten. Toevallig kwam er nu, ook juridisch bezien, iets goeds uit de bus. De Besluiten uit de bezettingstijd hebben echter een ernstig bezwaar voor het rechtsleven, nl. dat er geen officiële stukken als Memorie van Toelichting, Voorlopig Verslag enz. bestaan, waaruit later bij interpretatie der betreffende bepalingen door de rechter de gronden en motieven van ontwerper en wetgever geput kunnen worden, zodat de rechtsonzekerheid hierbij groter is. Meermalen is op dit euvel gewezen; laatstelijk nog door de Gaay Fortman in zijn artikel in ,Sociaal Maandblad". September 1949.

Naar wij hopen en verwachten zullen de beide Kamers der StatenGeneraal nu het goed voorbereid Gewijzigd Ontwerp met de bewaringstermijn van tien jaar, die ook in België geldt, aannemen. De zaak is thans reeds nauwlettend van alle kanten bekeken en overwogen. Genoemd werd reeds het vóóronderzoek in de Vaste Commissie voor Privaat- en Strafrecht. Daarna heeft de Regering nog de Staatscommissie tot herziening van de burgerlijke wetgeving, de Raad van State en ook de Kamers van Koophandel en Fabrieken - de laatste als belangrijke vertegenwoordiging van het bedrijfsleven - gehoord. Zowel de Staatscommissie, als de meeste Kamers van Koophandel en Fabrieken gaven de voorkeur aan de termijn van tien jaar in plaats van die van dertig jaar.

Laat de volksvertegenwoordiging nog wel even aandacht schenken aan een artikel in het Wetboek van Koophandel, dat tot nu toe waarschijnlijk aan de aandacht ontsnapt is. Wij bedoelen artikel $56 \mathrm{~h}$ van dit Wetboek, dat t.a.v. een geliquideerde naamloze vennootschap bepaalt: „Tenzij bij de akte van oprichting hieromtrent anders is bepaald, blijven na afloop der vereffening de boeken en bescheiden der ontbonden naamloze vennootschap gedurende dertig jaren berusten onder de persoon, daartoe aangewezen bij de akte van oprichting of, bij gebreke van zodanige aanwijzing, door de algemene vergadering benoemd". Wanneer artikel 6 een algemene bewaarplicht van tien jaren zal behelzen en artikel $56 \mathrm{~h}$, lid 1 de bewaarplicht van 30 jaar blijft voorschrijven, betekent dit een verschil in bewaarplicht, dat - mr Rutgers wees erop in zijn bovengenoemd boek over de boekhouding in het Nederlandse recht "door niets gerechtvaardigd" is (blz. 117).

Tot slot van bovenstaande beschouwingen wil ik op deze plaats niet nalaten te vermelden, dat artikel 3, lid 2 van het in 1946 herzien Reglement van Arbeid van het Nederlands Instituut van Accountants, volgens hetwelk voor de leden een plicht tot bewaring der aantekeningen gedurende tien jaren bestaat, bij aanneming van het Gewijzigd Wetsontwerp in overeenstemming zal zijn met de wettelijke, strafrechtelijk gesanctionneerde bewaarplicht van artikel $6 \mathrm{~W}$. v. K., zodat er geen divergentie tussen reglementaire plicht als lid der vereniging en wettelijke verplichting (voorzover uitoefenende een bedrijf) voor de N.I.V.A. leden ontstaat. 